\title{
Cystic Partially Differentiated Kidney Nephroblastoma
}

National Cancer Institute

\section{Source}

National Cancer Institute. Cystic Partially Differentiated Kidney Nephroblastoma. NCI

Thesaurus. Code C6897.

A variant of Wilms tumor of the kidney characterized by the presence of cystic spaces separated by septa. The septa contain immature epithelial cells, immature stromal cells, and blastema cells. Surgical resection is usually curative. 